\title{
形状記憶合金のゴム状弾性と 短範囲規則構造
}

丸 川 健三郎* 土 谷 浩 一**

\section{1.はじめに}

形状記憶合金は与えられた条件下で特徵的な擬弾性を示す 場合が多いが，その擬弾性として良く知られているものは 2 種類ある.1つは超弾性 (superelasticity), 他の 1 つがこの 小論のテーマであるゴム状弾性 (rubber-like behavior)であ る.これらはいずれもマルテンサイト変態に関係しており, ともに大きな擬弾性歪久が生じるが，その出現の状況は両者 でかなり異なっている。

図 1 (a)に示したよらに, 超弾性では母相状態の試料に応 力を加えることによりマルテンサイト相へと変態し, その変 態歪みに対応する変形が生じるが, 除荷すると母相へと逆変 態し，その歪みも消隇する。 この様子は以下のように表現で きる(右辺が応力下での状態である).

$$
\text { 母相 } \Leftrightarrow \text { マルテンサイト相 }
$$

つまりこの現象は応力誘起相変態であり, 応力によって誘起 されたマルテンサイト相が, 除荷するとその温度での安定相 である母相にもどることによって起こる. この際の復元の駆 動力は両相の自由エネルギーの差である.

それに対して，ゴム状弾性はマルテンサイト相単相で起こ る現象であり，相変態は関与していない。図 1(b)でヴァリ アント 1,2 は同じマルテンサイト相の兄弟晶であり，互い に双晶の関係にある. このようなマルテンサイトに応力を加 えたとき，その荷重方向に大きな歪みを与える方位のヴァリ アント（図のV1)の領域が増大し，その他のヴァリアント (V2)の領域は減少する.このヴァリアントの食い合いはそ

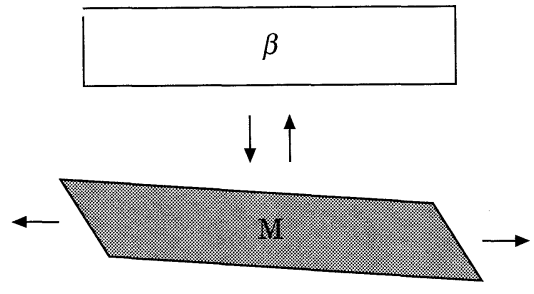

(a)

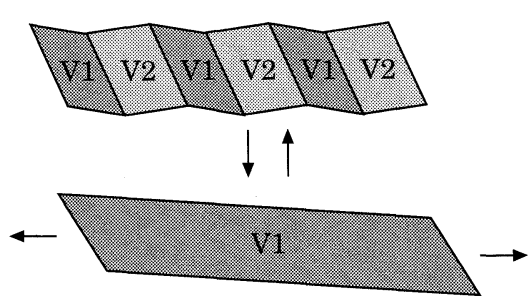

(b)

図 1 超弾性(a) とゴム状弾性(b)の模式図.

の境界が移動することによってなされる. その後, 除荷する ともとのヴァリアント配列が再現され, 歪みも消隇する.つ まり，ゴム状弾性では試料があたかも最初に与えられたヴっ リアント配列を記憶しているかのように振る舞らのである.

式 (1) に倣えば, この挙動は次のように書くべきであろ 丂.

$(\mathrm{V} 1+\mathrm{V} 2+\cdots \cdots)_{\text {マルテンサイト相 }} \Leftrightarrow(\mathrm{V} 1)_{\text {マルテンサイト相 }}$

* 北海道大学教授; 工学部応用物理学科

** 北海道大学助手; 工学部応用物理学科 (开060 札幌市北区北13条西 8 丁目)

Rubber-like Behavior and Short Range Ordering in Shape Memory Alloys; Kenzaburo Marukawa, Koichi Tsuchiya(Department of Applied Physics, Faculty of Engineering, Hokkaido University, Sapporo)

Keywords: martensitic transformation, rubber-like behavior, short range ordering, copper, zinc, aluminum, pseudoelasticity, aging, diffusion 1995年 6 月 14 日受理 
しかし，単純に考えると，同じマルテンサイト相のヴァリア ントはすべて同じ自由エネルギーを持つはずであり，除荷後 に元のヴァリアント配列が復元する理由は，一見，何もない ように思える。 Ölander によって初めて Au-Cd 合金のゴム 状弾性が見いだされたのは，実に60年以上も前のことであ るが(1), 現在にいたってもその理由については定説がない。

筆者らはここ数年，銅系形状記憶合金の時効に関する研究 を行ってきたが，最近，ゴム状弾性が時効による短範囲規則 構造の変化によって説明できることに気がついた ${ }^{(2)}$.

以下，この挙動に関する実験事実を振り返りつつ，その機 構についての筆者らのモデルについて述べていく.

\section{2. これまでの研究}

Ölander 以後, 現在に至るまでゴム状弾性挙動について種 々の研究が行われてきた(初期の研究についてはOtsuka and Wayman によるレビュー(3)に詳しい). その結果，この 挙動が Au-Cd 合金にのみ見られる現象ではなく，いわゆる 熱弾性型のマルテンサイト変態を示す合金に拈いてかなり広 範に見られることが明らかになった。例を挙げると， $\mathrm{Au}-\mathrm{Cd}$

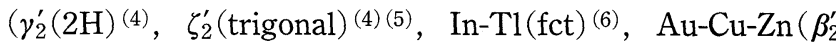
$(18 \mathrm{R}))^{(7)}, \mathrm{Cu}-\mathrm{Zn}-\mathrm{Al}\left(\beta_{1}^{\prime}(9 \mathrm{R}), \quad \beta_{2}^{\prime}(18 \mathrm{R})\right)^{(8)(9)}, \mathrm{Cu}-\mathrm{Al}-\mathrm{Ni}\left(\gamma_{2}^{\prime}\right.$

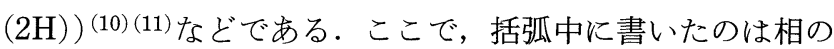
名称と結晶構造の略号である，以下，この節では各種合金の マルテンサイト相に見られるゴム状弾性の特徵を，筆者らに よる $\mathrm{Cu}-\mathrm{Zn}-\mathrm{Al}$ 合金についての研究 ${ }^{(9)}$ を主な例にとって述べ る.

一般に生成直後のマルテンサイト相はゴム状弾性を示さ ず，適当な時間の時効の後に初めてこの性質が現れる。ただ し In-T1 合金のマルテンサイト相は例外であり，生成直後か らゴム状弾性を示すがこれについては後述する，図 2 は，均 質化処理温度 $(1133 \mathrm{~K})$ から直接, 水中 $(285 \mathrm{~K})$ に焼き入れて 生成した $\mathrm{Cu}-14$ 原子 $\% \mathrm{Zn}-17$ 原子 $\% \mathrm{Al}$ 合金の $\beta_{2}^{\prime}$ マルテンサ イトの応力歪み曲線が，室温時効とともにどのように変化す るかを示したものである.引張試験は $278 \mathrm{~K}$ の水中で, 歪 又速度 $9.3 \times 10^{-4} \mathrm{~s}^{-1}$ で行った．生成直後は比較的低い応力 で変形が進行し, 除荷しても歪みが残留する $((\mathrm{a}))$. この際
の歪みがヴァリアント再配列によるものであることは試験中 に表面起伏が次第に消滅することからも明らかである. 900 $\mathrm{s}$ 室温時効した後の応力歪み曲線 ( (b)) では, 降伏点が見ら れるよらになる．さらに時効を続けると変形応力が著しく増 加し, 残留歪みは減少する ((c)). この合金では $12 \mathrm{ks}$ の時 効でほぼ完全なゴム状弾性を示すようになった ( d $))$. この ような応力歪又曲線から得た見かけの降伏応力と回復歪み率 を，時効時間の関数としてプロットしたのが図 3 である. 約 $10 \mathrm{ks}$ の時効で変形応力. 回復歪み率ともにほ汇飽和值 (最 大値) に達する。

同様な実験を，均質化後に $673 \mathrm{~K}\left(>M_{\mathrm{s}}\right)$ で $1.8 \mathrm{ks}$ 保持し た後に焼き入れた試料について行った結果を図 4 に示す. 図 で明らかなように, 前述の直接焼き入れ試料の結果と比較す ると, 同程度の応力上昇を得るのに要する時効時間は 10 倍 以上長かった。これは, 直接焼き入れと 2 段階焼き入れで は試料中に凍結される原子空孔の濃度が違らためであると思 われ，ゴム状弾性発現の kinetics が拡散支配であることを 裏付けるものである. 同様な結果が最近 $\mathrm{Au}-\mathrm{Cd}$ 合金の $\zeta_{2}^{\prime}$ マ ルテンサイトについて得られている(5).

このよらな変形応力の時間依存性を最初に示したのは, Birnbaum and Read によるごく初期の論文(4)である。この

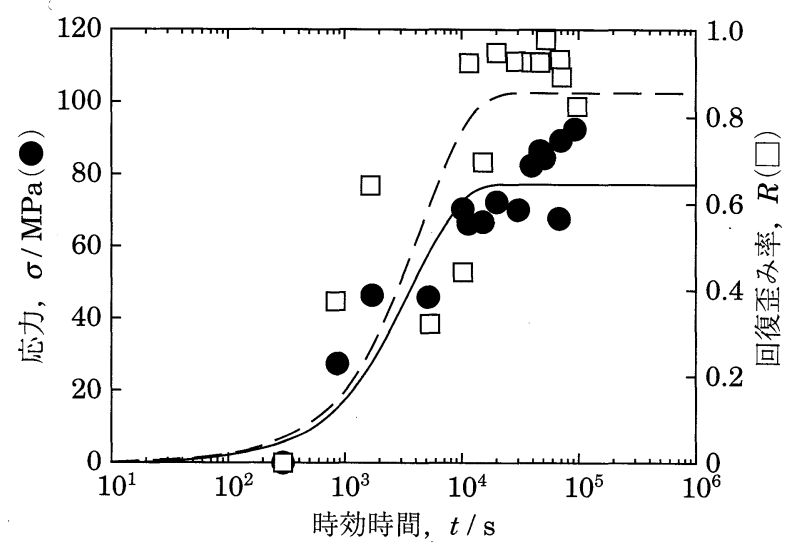

図 $3 \mathrm{Cu}-14$ 原子 $\% \mathrm{Zn}-17$ 原子 $\% \mathrm{Al}$ 合金マルテンサイ 卜相の変形応力と回復歪及率の時効時間への依 存 ${ }^{(9)}$.
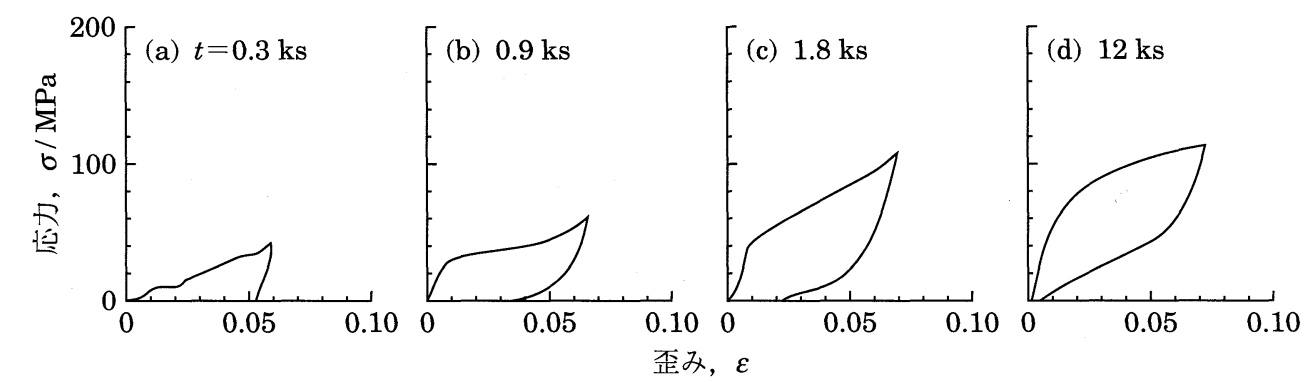

図 $2 \mathrm{Cu}-14$ 原子 $\% \mathrm{Zn}-17$ 原子 $\% \mathrm{Al}$ 合金マルテンサイト相の応力歪み曲線の時間変化 ${ }^{(9)}$. $t$ は室温での時効時間. 


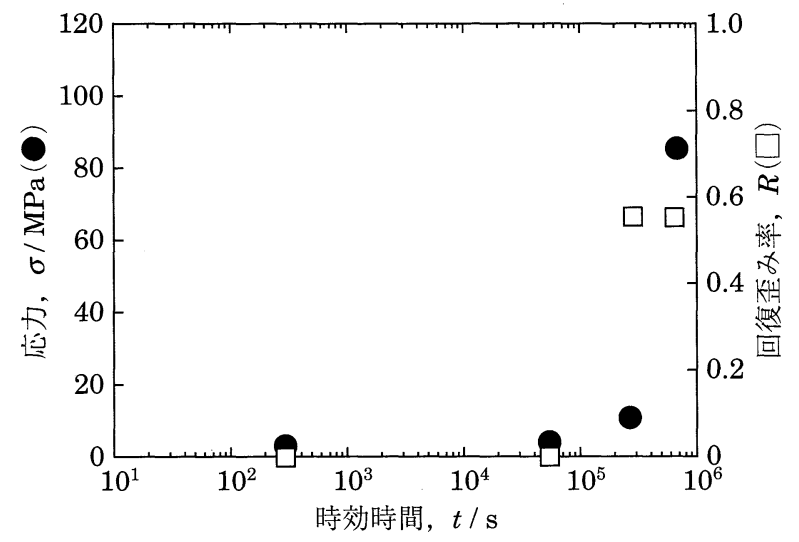

図 42 段階焼き入れした $\mathrm{Cu}-14$ 原子 $\% \mathrm{Zn}-17$ 原子 $\% \mathrm{Al}$ 合金マルテンサイト相の変形応力と回復歪み率 の時効時間への依存 ${ }^{(9)}$.

性質はゴム状弾性発現の機構を解明するためにきわめて重要 なものであるが，その後の研究で提案されたモデルは， Birnbaum ら自身によるものも含めて，何れもこの点をらま く説明できていない.

Miura らは，In-T1 合金の超弾性とゴム状弾性についてそ の温度，組成，ならびに歪み速度への依存に関する詳細な実 験を行った ${ }^{(6)}$. この合金は母相が不規則 fcc，これを冷却す ると fct マルテンサイトへと変態する. 前述のようにこのマ ルテンサイトは生成直後からゴム状弾性を示す。またその応 力歪み曲線は温度のみならず，雪み速度にも大きく依存して 変化し，歪み速度が遅いと回復歪みが小さくなる。これか ら，この合金においても，ゴム状弾性はある程度の時間依存 性を示し，拡散の影響下にあるらしいことが分かる．時効の 必要がないのはこの合金の融点がかなり低く( 423 K), 低 温に打いても，拡散係数が非常に大きいためであろう。

以上の結果より, ゴム状弾性は, 時効中にマルテンサイト 相内での拡散によって生じる，何らかの構造変化が原因では ないかと推測される，そのような構造変化はこれまでに観測 されているのだろらか？

Ohba ら ${ }^{(12)}$ は， $\mathrm{Au}-47.5$ 原子\% $\mathrm{Cd}$ 合金 $\left(\gamma_{2}^{\prime}(2 \mathrm{H})\right.$ マルテン サイト相の, X 線回折プロファイルの時間依存を詳しく調 ベた. その結果は, 時効後もピークの強度・位置は全く変化 せず，僅かにプロファイルの対称性が変化するのみであっ た. 同様な結果が他の合金についても報告されている(13). このことは，時効により大きな変形応力上昇があるのにもか かわらず，格子定数などに反映されるよらなマルテンサイト 相の平均構造の変化は, 非常に小さいことを意味している.

$\mathrm{Au}-47.5$ 原子\% Cd合金のゴム状弾性については, Lieberman ら ${ }^{(14)}$ がその原因となるような構造変化について のモデルを提案している. 一般に，多重格子構造の結晶の双 晶変形では，双晶剪断変形(twinning shear)だけでは空間格
子は保存されても結晶構造は保存されず, さらに原子の微小 変位(shuffling)が必要である. Liebermanらはこの shuffling が時間に依存して起こると仮定した。このモデルによ ると, 応力により双晶境界が移動した直後は, shuffling が 起こっていないためにその領域は不安定であり，除荷すると もとの配列が復元する. しかし shuffling が完了するまで時 効すると新しい配列が安定となる. 彼らはこれに関連して $\mathrm{Au}-47.5$ 原子 $\% \mathrm{Cd}$ 合金の $2 \mathrm{H}$ マルテンサイト相の時効中に $\mathrm{X}$ 線回折強度が最大で約 $6 \%$ 減少すると報告して扣り，この 強度変化が shufflingによるものとしている.

しかし，このモデルによると生成直後のマルテンサイトも ゴム状弾性を示すはずであり, 変形応力の時間依存性を説明 できない。前述の研究で Ohba らは, Lieberman らの提案 した shuffling が起こったときに予想される構造因子の変化 を計算した。その結果は Lieberman らの測定とも Ohba ら 自身の測定とも一致せず，上述の shuffling モデルを否定す るものとなった ${ }^{(12)}$.

$\mathrm{X}$ 線による回折実験以外に, 合金中の構造変化を比較的 簡単に検知する手段として電気抵抗率の測定がある. 筆者ら による $\mathrm{Cu}-14$ 原子 $\% \mathrm{Zn}-17$ 原子 $\% \mathrm{Al}$ マルテンサイト相の室 温時効による残留抵抗変化の測定值を図 5 に示した。測定 は, 直流 4 端子法により, 液体窒素中で行った. 時効とと もに抵抗率は減少している.この変化は例えば空孔等の格子 欠陷密度の変化から期待される值よりも大きく, 規則構造の 変化によるものではないかと推測される(15)(16).

Barceló ${ }^{(8)}$ は, Cu-Zn-Al 合金に引張応力を負荷して得 た単一ヴァリアントのマルテンサイトを時効し，その後の圧 縮変形によって現れるゴム状弾性について調べた。この場 合, 試料にヴァリアント境界が存在しない状態で時効してい るので，この結果はゴム状弾性がヴァリアント界面での構造 変化ではなく，ヴァリアント内部の変化に原因があることを 示している. 彼らはまた，母相の汪ぼ完全な L $22_{1}$ 構造を引 き継いだマルテンサイト中に熱平衡的に存在する不規則原子

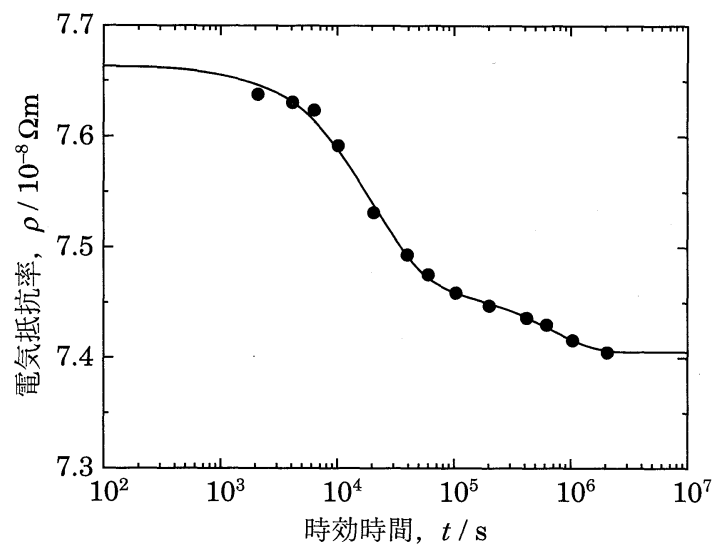

図 $5 \mathrm{Cu}-14$ 原子 $\% \mathrm{Zn}-17$ 原子 $\% \mathrm{Al}$ 合金マルテンサイ ト相の残留抵抗の時効時間への依存. 


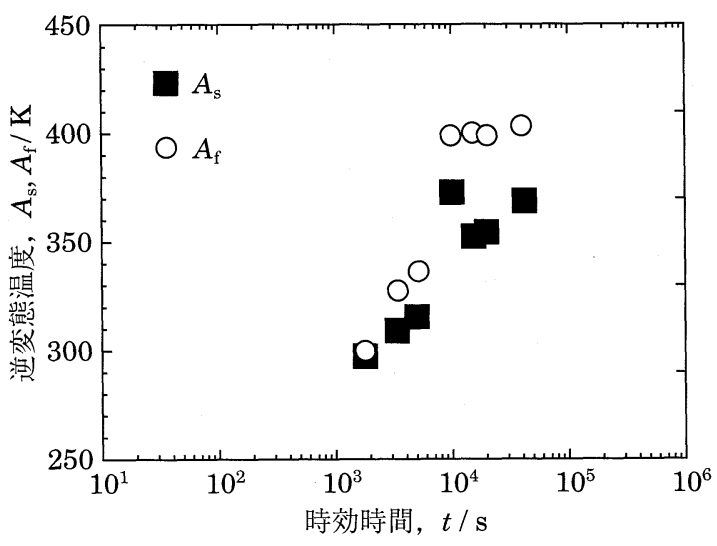

図 $6 \mathrm{Cu}-14$ 原子 $\% \mathrm{Zn}-17$ 原子\% $\mathrm{Al}$ 合金マルテンサイ 卜相の逆変態開始温度 $A_{\mathrm{s}}$ と終了温度の時効時間 への依存 ${ }^{(9)}$.

対の存在を仮定し，その周囲でのヴァリアント交代による原 子配列の変化が自由エネルギーの上昇をもたらすといらモデ ルを提案した ${ }^{(17)}$. しかし，このモデルも応力の時間依存と の関連が不明瞭であり，さらに $\mathrm{L}_{1}$ 型構造にしか適用でき ないといら難点を持っている.

ゴム状弾性以外に $\mathrm{Cu}-\mathrm{Zn}-\mathrm{Al}$ 合金のマルテンサイトの時効 効果として知られているものに，その逆変態温度が著しく上 昇する，いわゆる安定化現象がある. 図 6 は既述の合金に括 ける逆変態温度の時効時間への依存性を調べた結果である ${ }^{(9)}$. この図と図 3 との比較により, 安定化による変態温度変化 とゴム状弾性に括ける変形応力の上昇は滦滦同じ時間依存を 示すことが明らかである.このような 2 つの時効効果の間 の強い相関は，これらが同じ原因によるものであることを示 唆していると思われる.
この節で述べてきた実験事実を総括すると，ゴム状弾性の モデルは少なくとも以下の要求を満たさなくてはならないこ とが分かるであろう。

(1) 応力-歪みサイクルに拈ける復元駆動力を説明できる こと.

(2) 合金の種類や，結晶構造によらず適用できるモデルで あること。

(3) 時効の効果, 特に変形応力の時間依存性を説明できる こと.

(4) 時効による構造変化はマルテンサイトの平均構造を変 えないものであること。

(5) ヴァリアント界面の有無に無関係なモデルであるこ と.

次節ではこれらの条件を満たすべく，最近著者らが提案し たモデル(2)について説明する.

\section{3. ゴム状弾性の短範囲規則構造 (SRO) モデル}

まず，上述の(5)上り考兄られるように，ゴム状弾性の原因 となる構造変化としては試料中に均質に起こるものを考兄な ければならないであろう。このようなものとして長範团規則 構造と短範囲規則構造がある. もし時効によってこれらの構 造が変化すれば当然自由エネルギーが変化するのでゴム状弾 性の復元駆動力を与えるかもしれない，しかしこれらのらち 長範囲規則構造が不適当であることは容易に説明できる。つ まり長範囲規則度を与える各サイトの平均占有確率はヴァリ アント交代に括いても変化しないので，ゴム状弾性の駆動力 とはなり得ないのである。これに対し, 短範囲規則構造は以 下に示すよらにヴァリアント交代で変化するので復元駆動力 を与えることができる，さらに上記，(2)〜(5)の条件を満たす

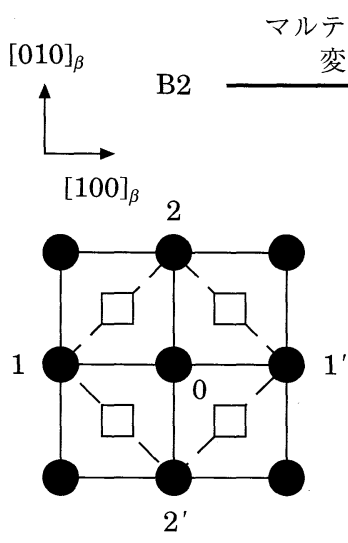

(a)

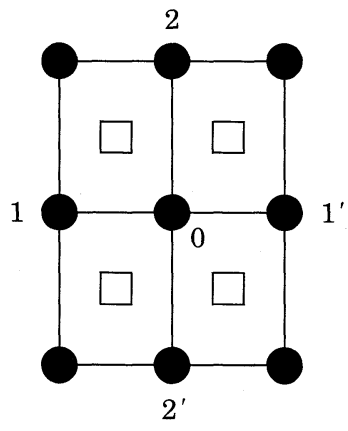

(b)

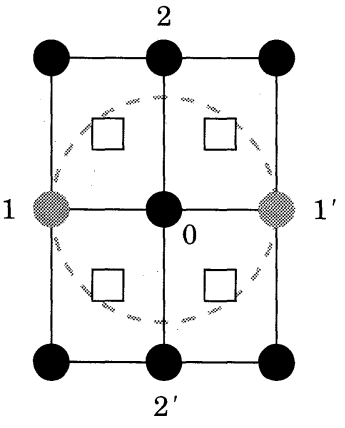

(c)

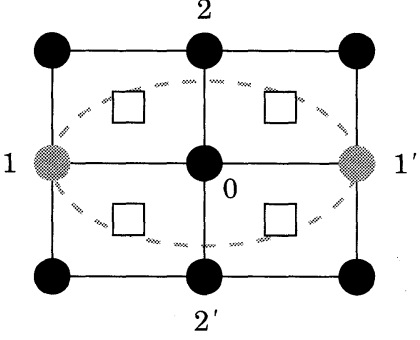

(d)

図 7 (a) B2 構造の母相に拈ける原子配列の (001)面上への投影. (b) (a)がベイン変形により $[010]_{\beta}$ 方向に伸長し てできた $\mathrm{L} 1_{0}$ マルテンサイト相. (c) 時効後のマルテンサイト相. (d) (c)のベイン軸が $[100]_{\beta}$ へと変化して でさるマルテンサイト相. 
ことも明らかで，ゴム状弾性の原因としてきわめて有力な候 補と思われる. 以下, 復元駆動力についてさらに定量的な評 価を試みる。

ここでは簡単のために取り扱ら系を 2 元系合金 $\left(\mathrm{A}_{1-x} \mathrm{~B}_{x}\right)$ として話を進めるが，若干の修正により 3 元系合金にも適

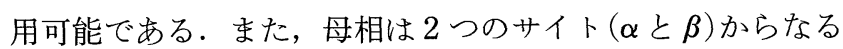
B2 構造とする.図7(a)に示したのは母相の原子配列を $(001)_{\beta}$ 上に投影したものである. 黒のシンボルは $\alpha$ サイト， 白は $\beta$ サイトを表す。これを冷却すると 3 つの $\langle 100\rangle_{\beta}$ 軸の 何れかをべイン軸としてマルテンサイト相へと変態する.こ こではマルテンサイト相の構造を $\mathrm{L1}_{0}(3 \mathrm{R})$ であるとする. 図 7(b) は(a)が $[010]_{\beta}$ は方向に伸長してできたマルテンサ イト相(ヴァリアント 1 とする)である. 良く知られている ようにマルテンサイト変態は無拡散変態であるので, 原子の 規則配列は母相からマルテンサイト相へと直接継承される. つまり変態直後のマルテンサイト相は母相で安定な原子配列 を行きがかり上，譲り受けていると言える．ただし，それが 必ずしもマルテンサイト相で安定な原子配列と一致するとは 限らないので, 時効すると原子の再配列が起こる.

ここで図 $7(\mathrm{a})$ と (b) に示した原子配列とその自由エネルギ 一の関連についてもら少し詳しく検討してみる. 一般に, 温 度 $T$ に拈ける合金の自由エネルギー $G$ は以下のように表さ れる。

$$
G=H-T S
$$

ここで $H$ はエンタルピー, $S$ はエントロピーを表す.エン タルピーは合金濃度に依存する純金属項, $H_{\text {ave }}$, と合金項, $H_{\text {ord }}$ ，の和で表されるが，前者は原子配列に依らないので以 下の議論では考察する必要がない。またエントロピーは原子 配列項と熱振動項に展開できるが，ゴム状弾性に関する限り 重要ではないのでこれ以上述べない.

規則合金中の原子配列は，各種の確率変数によって記述で きる、例えば， $P_{\mathrm{A}}^{\alpha}$ は $\alpha$ サイト上に A 原子のある確率， $P_{\mathrm{AB}}^{(1)}$ は第 1 最近接にある原子対が異種原子対である確率を表す. また， $P_{\AA \mathrm{B}}^{(i)}$ はボンドの両端のサイトに着目すると両端が異種 サイトである確率 $P^{(i \mathrm{~d})}$ と, 同種サイトである確率 $P^{(i \mathrm{~s})}$ に 分けられる. 合金エンタルピーが原子対間の相互作用でのみ 記述されるとすると，

$$
H_{\text {ord }}=\sum_{n} \frac{Z^{(n)}}{2} \Phi_{\mathrm{AB}}^{(n)} P_{\mathrm{AB}}^{(n)}
$$

のように表現される。ここで $Z^{(n)}$ は第 $n$ 近接配位数, $\Phi_{\mathrm{AB}}^{(n)}$ は対交換エネルギーである.

図 7 (a)の母相中では, 最近接原子対はすべて異種サイト同 士, 第 2 近接原子対は同種サイト同士のボンドであるの で, $P_{\mathrm{AB}}^{(1)} \equiv P^{(1 \mathrm{~d})}, P_{\mathrm{AB}}^{(2)} \equiv P^{(2 \mathrm{~s})}$ となる. Bragg-Williams-Gorsky 近似を用いると, これらは濃度 $x$ と長範囲規則度パラメータ $\eta\left(\equiv\left(P_{\mathrm{A}}^{\alpha}-P_{\mathrm{A}}^{\beta}\right) / 2\right)$ を用いて，以下のように表される。

$$
\begin{aligned}
& P^{(1 \mathrm{~d})}=2 x(1-x)+2 \eta^{2} \\
& P^{(2 \mathrm{~s})}=2 x(1-x)-2 \eta^{2}
\end{aligned}
$$

このような原子配列の母相がマルテンサイト変態を起こし て, 図 7(b)の $\mathrm{L}_{0}$ 相になった直後の最近接異種ボンド確率 は

$$
\begin{aligned}
P_{\mathrm{AB}}^{(1)} & =\frac{8}{12} P^{(1 \mathrm{~d})}+\frac{4}{12} P^{(2 \mathrm{~s})} \\
& =2 x(1-x)+\frac{2 \eta^{2}}{3}
\end{aligned}
$$

となる。式( 5 )と式 (7)を比較して分かるよらに, マルテ ンサイト変態によって $P_{\AA B}^{(1)}$ の值は低下する。なぜならばマ ルテンサイト相に和ける 12 本の最近接ボンドのらち，4 本は

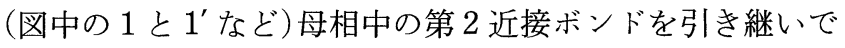
いるからである. このマルテンサイトを時効すると, 一旦低 下した $P_{\mathrm{AB}}^{(1)}$ が増加するように, すなわち短範囲規則構造が 発達するように原子の再配列が起こり, 系のエネルギーは低 下する. 図 7 (c) 中に破線で示した円は，0原子を中心とし 最近接原子間距離を半径とする球の投影である. この球内で は時効により異種原子対の存在確率が増加する.このよらな 時効後のヴァリアント 1 における $P$ AB る.

$$
P_{\mathrm{AB}}^{(1)}(\mathrm{V} 1)=\frac{8}{12} P^{(1 \mathrm{~d})^{*}}+\frac{4}{12} P^{(1 \mathrm{~s})^{*}}
$$

ここで, *は各量の時効後の值を示す.

ゴム状弾性はこのような時効されたマルテンサイト相で発 現すると考えられる. 図 $7(\mathrm{~d})$ は時効後荷重を負荷すること によってベイン伸長軸が変化し，ヴァリアント 1 がヴァリ アント 2 へと変化した時の様子を表したものである.

一見して明らかなのは，ヴァリアント変化によって，破線 円が棈円形に変化していることである.これは短範囲規則構 造がヴァリアント変化では保存されないことを示す.さらに

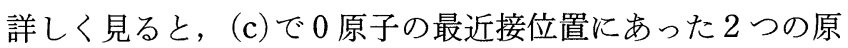
子 $\left(1\right.$ と $\left.1^{\prime}\right)$ が (d)では第 2 近接位置にあり, それに変わって, 第 2 近接位置にあった原子 $\left(2\right.$ と $\left.2^{\prime}\right)$ が新たに最近接原子とな っている. したがってこの時, ヴァリアント 2 内での異種 ボンド確率は

$$
P_{\mathrm{AB}}^{(1)}(\mathrm{V} 2)=\frac{8}{12} P^{(1 \mathrm{~d})^{*}}+\frac{2}{12}\left(P^{(1 \mathrm{~s})^{*}}+P^{(2 \mathrm{~s})^{*}}\right)
$$

と表される. したがって図 7 (c) と (d) の状態の間の自由エネ ルギーの差は,

$$
\Delta H_{\text {rubber }}(\mathrm{V} 1 \longrightarrow \mathrm{V} 2)=\Phi_{\mathrm{AB}}^{(1)}\left(P^{(2 \mathrm{~s})^{*}}-P^{(1 \mathrm{~s})^{*}}\right)
$$

となる. 一般に短範囲規則構造の発達にようて最近接対の異 種ボンド確率は第 2 近接のそれより高くなるので, 上式の 括弧内は負である. また規則合金では $\Phi_{A B}^{(1)}<0$ であることに 注意すれば上式がヴァリアント交代による自由エネルギーの 増加を表していることが分かる. このエネルギー差は図 7 (d)で与えた外部の荷重と釣り合っているはずで，もし荷 重を除けば自然に元の(c)のヴァリアントへ戻るべきである. すなわち式(10)がゴム状弾性に特ける復元駆動力に相当し ているのである. 


\section{4. 実験との比較}

定量的に式 $(10)$ を見積もるには $P^{(1 \mathrm{~s})^{*}}, P^{(2 \mathrm{~s})^{*}}$ を求める必要 がある.そのためには, 前述の BWG 近似のような点近似 では不十分であり,さらに精度の高い計算が必要である。こ こでは正 4 面体近似のクラスター変分法(18) とより $P^{(1 \mathrm{~s})^{*}}{ }^{*}$ 打 よび $P^{(2 \mathrm{~s})^{*}}$ を求めた (ただし, 正 4 面体近似では $P^{(2 \mathrm{~s})^{*}}$ は直 接は求められないので, この項はクラスター法で求めた長範 囲規則度から算出した)。系を $\mathrm{Cu}-30$ 原子 $\% \mathrm{Zn}$ と仮定し， Hsu らによる $\Phi_{A B}^{(1)}$ の值 $\left(\Phi_{A B}^{(1)}=-290 k, k\right.$ はボルッマン定 数)を用いると， $\Delta H_{\text {rubber }}=175 \mathrm{~J} / \mathrm{mol}$ が得られた。

この值は次式によって変形応力， $\sigma$ に換算することができ る。

$$
\Delta H_{\text {rubber }}=\mu \sigma \gamma V
$$

ここで， $\mu$ はSchmid 因子， $\gamma$ はヴァリアント交代で生じる 歪み(マルテンサイト変態歪みで近似する)，Vはモル体積 である.これらに適当な值 $(\mu=0.37, \gamma=0.19$ and $V=7.6 \times$ $\left.10^{-6} \mathrm{~m}^{3}\right)$ を代入すると， $\sigma=327 \mathrm{MPa}$ が得られた. 実験によ って得られた応力は扮よそ $48 \mathrm{MPa}$ であり，理論值の括よ そ1/7であるが両者の比較にはいくつか留意すべき事項があ る。まず，理論值はあくまで室温での平衡構造に対応する值 であるのに対し，実験值はこの温度での約 $10 \mathrm{ks}$ の時効中に 発達した SRO に対応している。したがって，ここでの理論 值はあくまであその上限を与兄るるのと解釈されるべきであ ろら。ささに，各パラメータの值にもいくらかの誤差があ る。これらを考慮するとほぼ満足すべき一致が得られている と言えよう。

\section{5. おわりに}

筆者らによるSRO モデルはゴム状弾性についての重要な 実験事実を定性的にも，また定量的にもかなりらまく説明で きることを示してきた．SRO は時効により徐々に発達する と考兄られるので, 復元駆動力や変形応力の時間依存性が無 理なく説明できる。また，一般に合金の残留抵抗は $P_{\mathrm{AB}}^{(1)}$ に 比例して減少することが知られている(16)。したがって時効 により短範团規則構造が発達するといら仮定は, 残留抵抗が 減少するといら実験結果とも一致し, 相の平均構造が大きく 变化しないといら条件も満足する。また，短範囲規則構造は 様々な合金に存在することが知られているので，このモデル
は不規則合金を含む様々な合金系にも適用できると思われ る.

な拉，図6に示したようにゴム状弾性と安定化現象の間 に強い相間があることは明らかである。したがって安定化も SRO の変化が原因である可能性が強い，ただし安定化の方 が現象としてょり複雑であり，SRO 以外の寄与も無視でき ないかもしれない.現在，この現象について実験的・理論的 な検討を進めているところである。

\section{文献}

(1) A. Ölander: J. Am. Chem. Soc., 54(1932), 3819.

(2) K. Marukawa and K. Tsuchiya: Scrip. Metall. Mater., $32(1995), 77$.

(3) K. Otsuka and C. M. Wayman: Reviews on the Deformation Behavior of Materials, 2(1977), 81.

(4) H. K. Birnbaum and T. A. Read: Trans. Metall. AIME, 218(1960), 662.

( 5 ) Y. Nakajima, S. Aoki, K. Otsuka and T. Ohba: Mater. Lett., 21(1994), 271.

(6) S. Miura, M. Ito and N. Nakanishi: Scrip. Metall., 10(1976), 87.

( 7 ) S. Miura, S. Maeda and N. Nakanishi: Philos. Mag., 30(1974), 565.

( 8 ) G. Barceló, R. Rapacioli and M. Ahlers: Scrip. Metall., 12 (1978), 1069.

( 9 ) K. Tsuchiya, K. Tateyama, K. Sugino and K. Marukawa: Scrip. Metall. Mater., 32(1995), 259.

(10) H. Sakamoto, K. Otsuka and K. Shimizu: Scrip. Metall., 11(1977), 607.

(11) H. Sakamoto, Y. Kijima, K. Shimizu and K. Otsuka: Scrip. Metall., 15(1981), 281.

(12) T. Ohba, K. Otsuka and S. Sasaki: Mater. Sci. Forum, 5658(1990), 317

（13）大庭卓也，T. Finlayson，中嶋陽一，大塚和弘：日本金属学会 春期大会講演概要，(1995), 315.

(14) D. S. Lieberman, M. A. Schmerling and R. W. Karz: Ferroelastic "Memory", and Mechanical Properties in Gold-Cadmium, Shape Memory Effects in Alloys, Plenum Press, New York (1975), 203.

(15) P. L. Rossiter: The Electrical Resistivity of Metals and Alloys Cambridge University Press, Cambridge, (1987).

(16) W. Pfeiler: Acta Metall., 36(1988), 2417.

(17) M. Ahlers, G. Barceló and R. Rapacioli: Scrip. Metall. 12 (1978), 1075.

(18) R. Kikuchi: J. Chem. Phys., 60(1974), 1071.

校正時追記 : ごく最近ゴム状弾性について下記のレヴュー論文が発 表された。

R. W. Chan: Nature, 374(1995), 120. 